\title{
ЮРИДИЧЕСКОЕ ЛИЦО КАК СУБЪЕКТ ПРЕСТУПЛЕНИЙ О ЛЕГАЛИЗАЦИИ (ОТМЫВАНИИ) ПРЕСТУПНЫХ ДОХОДОВ
}

\section{A LEGAL ENTITY AS A SUBJECT OF CRIMES OF MONEY LAUNDERING}

A. Ivanov

Summary. The article is devoted to the problems of introducing criminal liability of legal persons for committing crimes for legalization (laundering) of criminal incomes, i.e. provided by Art. 174 (174.1) of the Criminal Code of the Russian Federation, the positions and views of scientists on the given problematics, advantages and lacks, international documents and foreign practice are analysed; the substantiation of necessity of introduction of criminal liability of legal persons for laundering is given.

Keywords: legalization, money laundering, criminal liability of legal entities, Convention, Rosfinmonitoring, administrative liability of legal entities, FATF, MONEYVAL.
B настоящее время в литературе достаточно остро обсуждается введение уголовной ответственностью юридических лиц. Тема юридического лица как субъекта уголовного права остается достаточно резонансной и дискуссионной и мнения специалистов разделились на сторонников и противников. Безусловно, вопрос об ответственности юридических лиц за такие преступления как преступления против жизни и здоровья граждан, против собственности и др. является спорным. Тяжело представить, как можно привлечь юридическое лицо к какой-либо ответственности за совершения, например, убийства. В то же время, по нашему мнению, логично будет говорить об уголовной ответственности юридических лиц по таким категориям преступлений как экономические, экологические, должностные.

Тема введения уголовной ответственности юридического лица достаточно объемная и требует отдельного исследования. Здесь мы лишь коснемся ее изучения на примере применения в нормах о легализации (отмывания) преступных доходов, предусмотренных ст. 174 (174.1) УК РФ - Легализация (отмывание) денежных средств или иного имущества, приобретенных лицом в результате совершения им (другими лицами) преступления [1].

\author{
Иванов Андрей Викторович \\ Аспирант, Институт Международного права \\ и экономики им. А.С. Грибоедова \\ zagorye@mail.ru
}

Аннотация. Статья посвящена проблемам введения уголовной ответственности юридических лиц за совершение преступлений за легализацию (отмывание) преступных доходов, т.е. предусмотренных ст. 174 (174.1) УК РФ, проанализированы позиции и взгляды ученых по данной проблематике, преимущества и недостатки, международные документы и зарубежная практика, даны обоснования о необходимости введения уголовной ответственности юридических лиц за отмывание.

Ключевые слова: легализация, отмывание, уголовная ответственность юридического лица, Конвенция, Росфинмониторинг, административная ответственность юридических лиц, ФАТФ, МАНИВЭЛ.

Начнём с краткой исторической справки. В Российской истории права известны случаи коллективной ответственности. Так в статьях 3-6 Пространственной Русской Правды устанавливается порядок взыскания виры за убийство на территории верви, если вервь отказывалась искать преступника. Под вервью понимается община. Другим документом, в котором можно увидеть коллективную ответственность целых населенных пунктов это Соборное Уложение 1649 г., где предусматривалось уголовное наказание за ряд преступлений таких как укрывательство, разбой и др. [3]. Ст. 123 УК РСФСР 1922 года предусматривала наказание в виде ликвидации религиозных или церковных организаций с конфискацией их имущества за присвоение себе административных, судебных или иных публично-правовых функций и прав юридических лиц [4]. В советский период намеки об коллективной ответственности в уголовном праве отсутствовали, в связи с отсутствием существования каких-либо форм собственности, кроме не иначе как государственной.

В российском уголовном законодательстве также отсутствует уголовная ответственность юридических лиц. В современном российском праве для юридических лиц присутствуют лишь нормы об административной и гражданско-правовой ответственности, которые 
внесены в в кодекс об административных правонарушениях, гражданский кодекс и налоговый кодекс.

Проведем анализ нарративов специалистов и их доводов по этому вопросу.

Главным аргументом противников является то, что в основе понятия вины в доктрине уголовного права РФ привилегирующие положение занимает психологического понимания вины, присуще лишь только одушевленным лицам, способным думать, мыслить, осознавать, и иметь умысел. Вот что пишет Н.Е. Крылова: «Представляется, что попытки сформулировать понятие «вины» юридического лица, отличной от вины его представителей и руководителей (а для них вина - это психологическое отношение к деянию и его последствиям в форме умысла или неосторожности), заранее обречены на провал» [5]. В литературе описаны возможные решения данной проблемы несколькими путями: 1) путем разделения субъекта преступления и субъекта уголовной ответственности [6]; 2) путем перехода от психологического понимания умысла к оценочному, изменения законодательную формулировку определения [7]. Понятие вины как в административном праве, так и в уголовном абсолютно идентичны: вина - это элемент субъективной стороны состава административного правонарушения (уголовного преступления), она определяется как психическое отношение субъекта к противоправному действию или бездействию и его последствиям. Не совсем понятно, почему при одинаковом определении вины, административная ответственность юридических лиц возможна, а уголовная нет?

В качестве решения проблемы ответственности юридических лиц предложено О.В. Хомичем в виде дополнения КоАП статьями идентичными, предусмотренным ст. 174 (174.1) УК РФ, но ограничить их применение в отношении юридических лиц [8].

Мы не можем поддержать данную позицию, поскольку, ничто не мешает таким же способом дополнить УК уголовной ответственностью юридических лиц, и аргументы к тому более весомее.

В.С. Давыдов считает нецелесообразным введение института уголовной ответственности юридических лиц за отмывание преступных доходов, поскольку соответствующих целей можно добиться и с помощью институтов административной и гражданской ответственности юридических лиц [9]. Данное утверждение В.С. Давыдова является неубедительным, потому что действующим КоАП РФ не предусмотрена административная ответственность за легализацию (отмывание) незаконных доходов. Ст. 15.27 лишь предусматривает ответственность за неисполнение требований законодательства о противодействии легализации (отмыванию) доходов, полученных преступным путем, и финансированию терроризма, одним словом, само лицо не легализовало (отмывало) свои или другого лица незаконные доходы [10].

Если продолжить проводить сравнительный анализ между уголовной и административной ответственности, можно добавить, что уголовная ответственность имеет более сдерживающие воздействие, чем административная, т.к. уголовное судопроизводство содержит более эффективные механизмы и инструменты, способные создать мощную доказательственную базу для подтверждения причастности к преступной деятельности, такие как как допрос, очная ставка, обыск, выемка документов, проведения различного рода криминалистических экспертиз и др. Также сроки давности привлечения к ответственности в административном праве намного короче, чем в уголовном. Согласно ст. 4.5 КоАП они составляют всего два месяца (а по делам, рассматриваемыми судьями - три месяца) с момента совершения правонарушения.

Сроки рассмотрение административного производства, согласно ч. 5 ст. 28.7 КоАП, составляют всего один месяц плюс допускается продление максимум еще на месяц. Достаточно сложно собрать доказательственную базу за столь короткое время. При расследовании уголовных дел по легализации (отмыванию) преступных доходов следствию первоначально необходимо собрать доказательства по предикатному преступлению, поскольку легализация (отмывание) является прикосновенным преступлением. Процесс сбора доказательств достаточно трудоемкий, в связи с тем, что включает в себя обильное количество следственных действий по сбору финансовых, бухгалтерских, банковских и иных документов, на основании которых назначаются и проводятся криминалистические экспертизы (почерковедческие, бухгалтерские и т.п.). Другой проблемой при расследовании дел о легализации (отмывания) является то обстоятельства что в последнее время преступления данной категории носят транснациональный характер, в связи с чем по уголовным делам требуется оформлять международные следственные поручения, срок исполнения которых не определен законом. Практика направления международные запросов по административному производству по делам об отмывании не имеет перспектив по причине долгих сроков ожидания их исполнения. Если еще принять во внимание, что преступление легализации (отмывания) преступных доходов может иметь множество эпизодов, из которых каждый должны быть доказан, то времени, отведенного для административного процесса, не хватит. В уголовном же процессе, согласно ст. 162 УПК, срок расследования составляет два месяца, далее может быть продлен руководителями соответ- 
ствующих следственных подразделений до двенадцати, а в исключительных случаях и более [11].

Что касается гражданско-правовой ответственности можно отметить, что гражданско-правовой деликт будет идеальной совокупностью, так как уголовное производство может также включать в себя такие обеспечительные меры как арест имущества, конфискацию, которые являются мерами по обеспечению возможного гражданского иска и возможной компенсации за причиненный ущерб. (Например, от неуплаты налогов). Аргумент возмещения, причиненного вреда является достаточно внушительным. У юридического лица больше возможности возместить, причиненный ущерб, нежели у физического.

Непонятно, кто конкретно будет нести уголовную ответственность, в случае принятия в корпорации неправомерного решения коллегиальным органом, возможно и при тайном голосовании, что безусловно вызовет трудности в определении того, кем конкретно принято незаконное волевое решение. Обычные руководители являются лишь только исполнителями, наряду с другими сотрудниками, которые воплощают решения корпорации (Совета директоров, общего собрания учредителей и т.д.). Более того, руководители могут постоянно сменяться по различным причинам (даже, например, в силу осуждения судом к наказанию, связанным с лишением свободы), а юридическое лицо остается и может продолжать осуществлять незаконную деятельность. Конечно, скептики здесь могут возразить, что юридическое лицо может реорганизоваться. Но в качестве превентивных мер или меры наказания можно предусмотреть временное, на время действия наказания, приостановление или запрет любой реорганизации конкретного юридического лица, либо, наоборот, принудительной реорганизации в организационно-правовую форму, подконтрольную государству. В этой связи большим подспорьем было бы предложение Л.А. Буклеровой и Ю.Б. Гаврюшкина, которые также предлагают рассмотреть вопрос об уголовной ответственности учредителей, участников, выгодоприобретателей и иных лиц, имеющих возможность определять решения о совершении сделок, принимаемые юридическим лицом, особенно когда документы юридического лица оформляются на подставных лиц, что позволит каждому лицу, готовому предоставить свои документы, понести уголовную ответственность за преступления, совершаемые созданной им, даже формально, фирмой [12]. Мы согласны с данной постановкой вопроса, поскольку сложная структура учредителей иногда делает невозможной идентификацию физических лиц, которые стоят за учредителями, т.к. в качестве учредителей иногда может выстраиваться целая вереница из других юридических лиц, которые могут быть или иностранными юридическими лицами или оффшорами.
Возможность привлечение юридического лица к уголовной ответственности за легализацию (отмывание) незаконных доходов создаст правовой инструмент для борьбы с фирмами-однодневками, позволит избежать постановки имущество, полученного незаконным путем на баланс предприятия, предотвратит корпоративную коррупцию.

Введение уголовной ответственности юридических лиц за легализацию (отмывание) может быть более рационально и иметь большую эффективность при профилактики такого рода преступлений. Зная последствия принятия полномочными лицами корпорации незаконных решений, которые могут привести к уголовному наказанию, вплоть до ликвидации самой организации и конфискации ее имущества, что побудит их обдумыванию и возможным отказом от своих преступных намерений. Американские фирмы, столкнувшиеся с судебными исками за подкуп, теряют в среднем 9\% своей рыночной стоимости [13].

Карательный эффект в виде наличия судимости за уголовное преступление за отмывание наносит репутационные последствия, что также является серьезным сдерживающим воздействием.

Еще одним аргументом противников уголовной ответственности юридических лиц является нарушение правила «Non bis in idem» (повторное привлечение к ответственности). Это правило действительно имеет важное значение поскольку может нарушать права человека. Данный принцип закреплен в статье 4 «Право не быть судимым или наказанным дважды» Протокола № 7 к Европейской конвенции 1950 года о защите прав человека и основных свобод [14]. Действительно, при привлечении к ответственности за легализацию (отмывание) преступных доходов, юридических лиц за данное же деяние может быть привлечено и физическое лицо, так как оно также является субъектом данного состава преступлений. Но, привлечение за легализацию (отмывание) как за одно и то же деяние одновременно физическое и юридическое лицо не будет является нарушением принципа «non bis in idem». И вот почему. Оба субъекта являются разными лицами и виновны в совершении одного и того же правонарушения в различном качестве: физическое лицо виновно в его совершении лично, тогда как юридическое лицо виновно, например, в том, что не предотвратило совершение этого правонарушения физическим лицом, только деяние этих субъектов будут отличаться по степени вины, физическое лицо будет иметь как прямой умысел, так и по неосторожности, а юридическое - по неосторожности.

Привлечение к уголовной ответственности руководителя или иного сотрудника корпорации за незакон- 
ные действия самого юридического лица нарушают принцип справедливости, предусмотренного ст. 6 УК. Действующий Уголовный закон дает возможность привлекать руководителя или иного сотрудника за действия, совершенные самим юридическим лицом, позволяя при этом избегать ответственности самому юридическому лицу. Также несправедливо и не логично привлекать юридическое лицо только к административной ответственности, а физическое лицо к уголовной.

Согласно ч. 3 ст. 10 Конвенции Совета Европы от 16.05.2005 г. № 198 «Об отмывании, выявлении, изъятии и конфискации доходов от преступной деятельности, и финансировании терроризма» (далее Варшавская Конвенция) [15], ответственность юридического лица не должна исключать уголовного судопроизводства в отношении физических лиц, являющихся исполнителями, подстрекателями или соучастниками преступлений за совершение преступлений по отмыванию денежных.

Имплементация международных документов, принятых международными и региональными организациями, членом которых также является РФ, и которая ратифицировала указанные соглашения без оговорок в части ответственности юридических лиц, в национальное законодательство, позволит соответствовать международными стандартами противодействию легализации (отмыванию) преступных доходов (далее ПОД).

Европейское сообщество также пошло по пути ужесточения мер ПОД, о чем свидетельствует принятие 23.10.2018 г. Европейским парламентом и Советом ЕС 6-й Директивы 2018/1673. Ст. 7 и 8 предусматривают возможность привлечения юридического лица к ответственности и список возможных наказаний для юридического лица [16]. РФ не является членом ЕС, однако РФ подписано Соглашение о партнерстве и сотрудничестве, учреждающее партнерство между Российской Федерацией, с одной стороны, и Европейскими сообществами и их государствами-членами, с другой стороны от 24.06.1994 г. [17], которое было ратифицировано РФ Ф3 от 25.11.1996 г. № 135-Ф3 «О ратификации Соглашения «О партнерстве и сотрудничестве» между РФ и ЕС» [18]. Согласно ч. 1 ст. 55 (Сотрудничество в области законодательства) Стороны признают, что важным условием для укрепления экономических связей между Россией и Сообществом является сближение законодательства. Россия стремится к постепенному достижению совместимости своего законодательства с законодательством Сообщества. А согласно ст. 81 («Отмывание» денежных средств), Стороны согласны с необходимостью принятия всех усилий по сотрудничеству с целью предотвращения использования своих финансовых систем для «отмывания» доходов от преступной деятельности в целом, и, в частности, от преступлений, связанных с наркотическими веществами. Сотрудничество в этой области включает административное и техническое содействие с целью выработки приемлемых стандартов в предотвращении «отмывания» денег, эквивалентных стандартам, принятым Сообществом и международными форумами по данным вопросам, включая Специальную группу по финансовой деятельности (ФАТФ).

Согласно ст. 5 ФЗ РФ от 15.07.1995 г. № 101-Ф3 «О международных договорах Российской Федерации» [19] и в соответствии с ч. 4 ст. 15 Конституции РФ «общепризнанные принципы и нормы международного права и международные договоры Российской Федерации являются составной частью ее правовой системы. Если международным договором Российской Федерации установлены иные правила, чем предусмотренные законом, то применяются правила международного договора».

Аналогичное разъяснение содержит постановление Пленума Верховного Суда РФ от 31.10.1995 г. № 8 «О некоторых вопросах применения судами Конституции Российской Федерации при осуществлении правосудия» (ред. от 03.03.2015). Согласно п. 5 Постановления судам необходимо иметь в виду, что в силу п. 3 ст. 5 Федерального закона Российской Федерации «О международных договорах Российской Федерации» положения официально опубликованных международных договоров Российской Федерации, не требующие издания внутригосударственных актов для применения, действуют в Российской Федерации непосредственно. В иных случаях наряду с международным договором Российской Федерации следует применять и соответствующий внутригосударственный правовой акт, принятый для осуществления положений указанного международного договора [20].

На невыполнение РФ своих обязательств в части введения уголовной ответственности юридических лиц неоднократно отмечали в своих докладах такие международные организации по ПОД, членами которых является РФ, как Группа разработки финансовых мер борьбы с отмыванием денег (ФАТФ) [21] и Комитет экспертов Совета Европы по оценке мер противодействия отмыванию преступных доходов и финансированию терроризма (МАНИВЭЛ) [22], которые подчеркивали, что административная ответственность юридических лиц является ограниченной, а наказания, предусмотренные в отношении юридических лиц, являются недостаточно сдерживающими. Бесспорно, международные-правовые документы носят рекомендательный характер, не являются строго обязательными, однако, но РФ следует придерживаться международных стан- 
дартов, поскольку РФ стало членом этих международных и европейских организаций, чем подтвердила приверженность общему мировому и европейскому курсу по преобразованию национальных законодательств согласно указанных рекомендаций. Введение уголовной ответственности юридических лиц позволило бы РФ интегрировать и гармонизировать отечественное законодательство в соответствии с международными стандартами и зарубежной практикой других государств, поскольку Международное и Европейского право вобрало в себя все прогрессивные преобразования и достижения развитых стран. Необходимо опираться на мировой опыт и опыт передовых зарубежных стран. На сегодня уже имплементирован уголовную ответственность в своих национальных законодательствах страны с различными правовыми традициями: Австралия, Великобритания, Бельгия, Венгрия, Испания, Италия, Канада, Китай, Корея, Люксембург, Нидерланды, США, Франции, Чехии, Швейцарии и др., тем самым создав успешную практику применения норм об ответственности юридических лиц за совершение отмывания преступных доходов.

Например, в ст. 324-9 УК Франции отражено, что юридические лица несут уголовную ответственность за отмывание [23]. Франция имеет достаточную практику применения указанной статьи. Примерами может служить приговор Парижского суда по уголовному делу, когда в феврале 2019 года швейцарский банк UBS AG был признан виновным в отмывании денег при отягчающих обстоятельствах и приговорен к штрафу в размере 3,7 миллиарда евро, в дополнение к 800000000 евро в виде ущерба французскому государству [24].

В РФ также делались попытки введения уголовной ответственности юридических лиц за легализацию (отмывание) путем представления в ГД РФ, разработанного Следственным Комитетом РФ, законопроекта «О внесении изменений в некоторые законодательные акты Российской Федерации в связи с введением института уголовно-правового воздействия в отношении юридических лиц», но к сожалению данный проект так и не был принят к рассмотрению [25]. В частности, в законопроекте предлагалось предусмотреть ч. 4 ст 174.1 со следующей формулировкой: «Деяние, предусмотренное частью первой настоящей статьи, совершенное юридическим лицом или в интересах юридического лица...». В качестве наказаний в указанном законопроекте были представлен достаточно широкий спектр наказаний: предупреждение; штраф; лишение лицензии, квоты, преференций или льгот; лишение права заниматься определенным видом деятельности; запрет на осуществление деятельности на территории РФ; принудительная ликвидация. Этот список мы бы дополнили еще таким наказанием как запрет на реорга- низацию с целью предотвращения возможного уклонения от наказания путем передачи своих активов вновь образованную фирму, либо принудительная реорганизация; участвовать в тендерах по определенным видам деятельности или с участием госзакупок; запрещение обращаться к населению с целью получения вкладов или размещения ценных бумаг; запрещение пускать в обращение чеки иные, кроме позволяющих строго установленных, помещение под судебный надзор.

Проблемы совершений противоправных деяний по легализации (отмыванию) доходов были отмечены в публичном отчете Росфинмониторинга «Национальная оценка рисков легализации (отмывания) преступных доходов за 2017-2018 гг.», согласно которого в противодействии легализации (отмыванию) денежных средств или иного имущества в РФ существуют следующие уязвимые места: использование номинальных юридических лиц (фирм-однодневок), вовлеченность отдельных представителей финансового сектора в оказание высокорисковых финансовых услуг; группа высокого риска это риск использования юридических лиц, а также структур без образования юридического лица (трасты) в схемах легализации преступных доходов в иностранных юрисдикциях в следующих сферах [26].

Подводя итоги еще раз перечислим преимущества введения уголовной ответственности юридических лиц за уголовные правонарушения в сфере легализации (отмывания) преступных доходов, которые заключаются в сохранении принципа справедливости; в более обеспечительных мерах при возможной конфискации и возмещении ущерба; в более эффективной борьбе с фирмами-одиночками; возможностью исключения избежания уголовной ответственности при совершении преступления по отмыванию доходов неустановленными лицами, которые тайно или коллегиально, прямо или косвенно участвовали в принятии незаконного решения; в более сдерживающем воздействии; в более обширном наборе следственных механизмов и принудительных мер; в более продолжительных сроках давности привлечения к ответственности; в более продолжительных сроках расследования; в более широких возможностях для международного сотрудничества в правовой сфере, включая взаимную правовую помощь; наличием апробированного многолетнего опыта многих зарубежных стран; в профилактике отмывания за счёт понимания юридическим лицом того, что судимость может привести к репутационных рискам.

Таким образом, преимущество уголовной ответственности юридического лица перед административной или гражданско-правовой за легализацию (отмывание) преступных доходов очевидно и является более эффективными инструментами ПОД. 


\section{ЛИТЕРАТУРА}

1. Уголовный кодекс Российской Федерации от 13.06.1996 г. № 63-Ф3 // Собрание законодательства РФ от 17.06.1996 г. № 25. Ст. 2954

2. Российское законодательство X-ХХ вВ. // Под общей ред. Чистякова 0.И. 1984. Т. 1. С. 36, 64, 83-86.

3. Указ. соч. Т. 3. С. 238-241.

4. Уголовный кодекс РСФСР от 01.06.1922 г. // СУ РСФСР.- 1922. -№ 15.

5. Крылова, Н.Е. Уголовная ответственность юридических лиц (корпораций): сравнительно-правовой анализ // Взаимодействие международного и сравнительного уголовного права: учеб. пос. / науч. ред. Н.Ф. Кузнецова, отв. ред. В.С. Комиссаров. М. 2009. С. $78-79$.

6. Волженкин, Б.В. Избранные труды по уголовному праву и криминологии. СПб. 2008. С. 793.

7. Алиев, В.М. Теоретические основы и прикладные проблемы борьбы с легализацией (отмыванием) доходов, полученных незаконным путем: дис. .... докт. юрид. наук. М. ВНИИ МВД РФ. 2001. С. 165.

8. Хомич, 0.В. Легализация (отмывание) преступных доходов: уголовно-правовое и сравнительно-правовое исследование: дис. ... канд. юрид. наук. M. 2019. C. 97.

9. Давыдов, В.С. Уголовная ответственность за легализацию (отмывание) денежных средств или иного имущества, приобретенных преступным путем: правовое регулирование в России и за рубежом: автореф. дис. .. канд. юрид. наук. СПб., 2006. С. 21.

10. Кодекс 06 административных правонарушениях (КоАП РФ) от 30.12.2001 г. № 196-Ф3 // Собрание законодательства РФ от 07.01 .2002 г. № 1 (часть І) ст. 1.

11. Уголовно-процессуальный кодекс Российской Федерации от 18.12.2001 г. № 174-Ф3 // Собрание законодательства РФ 0 т 24.12 .2001 г. № 52 (часть I) ст. 4921.

12. Букалерова, Л.А., Гаврюшкин, Ю.Б. К вопросу о введении института уголовно-правового воздействия в отношении юридических лиц // Пробелы в российском законодательстве. 2012. № 4. С. 167-170.

13. You get who you pay for. The Economist. 02.06.2012 г. www.economist.com, дата посещения 16.10.2021 г.

14. Бюллетень международных договоров, июль 1998 г., № 7.

15. Бюллетень международных договоров. Апрель 2018 г. № 4.

16. Директива Европейского Парламента и Совета (ЕС) от 23.10.2018 г. № 2018/1673 «По борьбе с отмыванием денег уголовным законодательством» // Официальный Журнал ЕC, № L 284.

17. Собрание законодательства РФ. 20.04.1998 г. № 16, ст. 1802, Бюллетень международных договоров, август 1998 г. № 8.

18. Собрание законодательства РФ. 02.12.1996 г. № 49. Ст. 5494.

19. Собрание законодательства РФ. 17.07.1995 г. № 29 ст. 2757.

20. Бюллетень Верховного Суда Российской Федерации, 1996 г., № 2, с. 1.

21. http://www.fatf-gafi.org/media/fatf/documents/reports/mer4/Mutual-Evaluation-Russian-Federation-2019.pdf

22. https://www.coe.int/en/web/moneyval/jurisdictions/russian_federation

23. Уголовный кодекс Франции // Под ред. Л.В. Головко. СПб. «Юридический центр Пресс», 2002. С. 336.

24. Швейцарский UBS оштрафовали на Є3,7 млрд. за неуплату налогов во Франции. Газета РБК. 20.02.2019 г. [Электронный pecypc: https://www.rbc.ru/fin ances/20/02/2019/5c6d51ca9a7947d6b321f510]

25. Электронный ресурс: [http://www.sledcom.ru/discussions/? SID=1273

26. Публичный отчет «Национальная оценка рисков легализации (отмывания) преступных доходов 2017-2018 гг.» // URL: http://www.fedsfm.ru. 